\title{
An Analysis of the Factors involved in Providing Parental Support for Developing Sport Talent in Early Childhood
}

\author{
Juriana Juriana $^{1, *}$, Yuli Rahmawati ${ }^{2}$, Muhamad Syarif Sumantri ${ }^{1}$, Dede Rahmat Hidayat ${ }^{3}$ \\ ${ }^{1}$ Faculty of Education, Early Childhood Education Doctoral Program, Universitas Negeri Jakarta, Indonesia \\ ${ }^{2}$ Faculty of Mathematics and Natural Sciences, Universitas Negeri Jakarta, Indonesia \\ ${ }^{3}$ Faculty of Guidance and Counseling, Universitas Negeri Jakarta, Jalan Rawamangun Muka 13220, Jakarta, Indonesia
}

Received December 9, 2020; Revised April 26, 2021; Accepted May 13, 2021

\section{Cite This Paper in the following Citation Styles}

(a): [1] Juriana Juriana, Yuli Rahmawati, Muhamad Syarif Sumantri, Dede Rahmat Hidayat, "An Analysis of the Factors involved in Providing Parental Support for Developing Sport Talent in Early Childhood," International Journal of Human Movement and Sports Sciences, Vol. 9, No. 4, pp. 682 - 696, 2021. DOI: 10.13189/saj.2021.090412.

(b): Juriana Juriana, Yuli Rahmawati, Muhamad Syarif Sumantri, Dede Rahmat Hidayat (2021). An Analysis of the Factors involved in Providing Parental Support for Developing Sport Talent in Early Childhood. International Journal of Human Movement and Sports Sciences, 9(4), 682 - 696. DOI: 10.13189/saj.2021.090412.

Copyright $\bigcirc 2021$ by authors, all rights reserved. Authors agree that this article remains permanently open access under the terms of the Creative Commons Attribution License 4.0 International License

\begin{abstract}
The first phase of sports coaching often determines whether children maintain an interest into the next phase of coaching, therefore, parental support for children's sports activities in early childhood is very important. This qualitative research aims to explore the four dimensions of social support: emotional support, instrumental support, informational support, and companionship support for developing sport talent in early childhood. In addition, the differences between the roles of fathers and mothers in providing social support are examined. Participants involved in the study were seven parents of children aged between 0-6 years, who were members of a track and field club which has a Super Kids program. Super Kids is a program aimed at training fundamental movement skills. Interviews and observations formed the basis of the research methods and data were analysed by taxonomic analysis with results indicating that all parents provided the four types of emotional support, instrumental support, informational support, and companionship support to their children. Support from the father and/or mother plays an important role in develop children's positive characteristics to engage in sport and develop their talents through coaching. The study found that parents who had educational backgrounds and/or work in jobs associated with sport were more confident in providing detailed informational support.
\end{abstract}

Keywords Early Childhood, Parental Support, Sport Talent

\section{Introduction}

Physical activity is very important in early childhood when the development of physical motor aspects is the most prominent. The benefits of physical activity in the early years are improved health, cognitive function, and academic abilities [1], [2]. Motor skills developed through physical activity provide opportunities for children to interact with the environment, thus encouraging the development of communication and language skill [3], [4]. According to [5], learning through group-based manipulative movement activities, delivered through appropriate programs to children aged $4-5$ years, have a positive impact on their socialization skills. Through physical activities, children interact intensively with each other in a supportive environment that provides the freedom to be creative, share roles, cooperate, and develop empathy. In recognition of the many benefits of physical activity in early childhood, the government of Finland requires that young children do light to heavy physical activity for at least three hours every day [6]. 
Sport is a form of organized physical activity that young children can participate in. Based on guidelines for sport coaches published by Long-Term Athlete Development (LTAD), children in early childhood can start sports coaching during what is termed the active start period from 0-6 years and during the fundamental development period of 6-9 years. During this latter period, children are taught fundamental movement skills and fundamental motor skills [7], [8]. As with the arts or science, sports talent can be identified from an early age. Traditionally, sports talent usually involves identifying only physical attributes. [9] criticizes the process of identifying football talent which, so far, uses only anthropometric measurements. [9] goes on to suggest that talent scouts should pay greater attention to four important predictors of football talent; the physical, physiological, psychological, and sociological aspects of development, a view shared by [10] in several articles published between 1985-2012. [10] found that, in detecting and developing football players' talents, physical, physiological, psychological, cognitive, and sociological factors were interrelated. This view is supported by Talent Identification and Development in Sports (TIDS), a term used in sports talent scouting programs in many countries today. The TIDS approach uses both children's intrinsic potential (physical, technical, tactical, psychological) and extrinsic potential (training, parental support [8], [11], [12]. Of these potentials, parental support is a sociological predictor used to identify the talents of novice and elite athletes, and aligns their approach to training as an extrinsic factor that determines whether a person can become an elite athlete in the future [11], [12].

In general terms, the role of parents is very important for the development of children from birth. Mothers who actively take their children to children a health center have a 3,238 times better chance of their children developing normally compared to mothers who do not actively visit a health center [13]. Parents also have an important influence on independence and discipline in early childhood [14], [15]. If parents have limited knowledge of child development, their ability to support children's growth and development, and learning processes, can be improved through systematically structured training and partnerships [16], [17].

The role and support of parents have a significant influence on children's participation in sports, including during the early childhood years. The process of initiating, and continuing sports participation in early childhood depends on parental support. The importance of parental support for engagement and enthusiasm for sports in young athletes is identified by and is one element used to measure novice athletes' commitment in sports [20]. Thus, it can be concluded that parents play an important role in identifying and supporting children in sports programs [21].

According to [22], in 2008-2009, millions of student-athletes in the United States participated in age-group sports competitions for children up to 18 years of age. [22] found that the families of student-athletes made considerable sacrifices while supporting their children to participate in sports competitions. Parental support constitutes emotional support (being able to provide comfort for children when they feel pressured in competition), financial support (providing financial support or providing the training equipment needed), and informational support (advice outside of sports, how to balance sports and other life achievements). According to [23] the development of children who participate in sports activities cannot be separated from the role of parents in supporting children's activities during training and competing. [23] identifies the dimensions of social support provided by parents as emotional support, reward support, instrumental support, and information support. [24] measures social support in the two dimensions of emotional support and instrumental support whilst [25] uses the terms emotional support and informational support. A biopsychosocial approach, used widely in health psychology, identifies four dimensions of social support: emotional support, instrumental support, informational support, and companionship support [26]. No research comprehensively explores parental support for children's sports participation [26].

The results of parent reflections show that parental support is diverse, unique and plays a very important role in achieving organizational goals [27]. Support from the father and mother is similar in the way enjoyment of exercise is encouraged in their children, however there are differences in the way roles were carried out [28]. Some forms of parental support are beneficial and others have adverse effects causing the child to stop exercising, experience fatigue or have a higher risk of injury [19], [28], [29]. However, according to [29], the family environment is the most accessible part of social support for young, high-achieving athletes. Parents of high-achieving athletes with prior experience in sport are usually more highly motivated to supporting their child's career. A study by [30] shows that parental involvement in training young athletes is influenced by the parents' understanding of age-appropriate sports demands, the influence of other parents, coaches and their attitudes, parents' knowledge and experience in sports, previous experiences of mentoring, and targets and beliefs about their child's achievement potential. Although there have been many studies on the difference between support from fathers and mothers, and their backgrounds, there has been no research that links these differences based on the four dimensions of social support [26].

Current research shows different parental support for children involved in sports activities during different years of age (6-13 and 13-15 years old) [19], [24], [27], [31], [32]. Research on the involvement, function, and role of parents on children's participation in sports is mostly from 
parents of young athletes aged 8 years and over, adolescents, and students to young adults [18], [24], [27], [29]. There has been no research done on parental support for athletes who are aged 0-6 years, as shown in figure 1.

Research into the influence of parental support on these early years children is very important considering that they are in the first phase of sports coaching which will determine their progression to the next phase of coaching. Research questions identified for this study are as follows:

1. How do parents support their children based on four dimensions of social support?

2. Are there differences between the support provided by the father and the mother based on the four dimensions of social support?

\section{Method}

This is a qualitative research study to find out how parents support their children in sports activities at the 0-6 age group and whether there are differences in the support provided by the father and mother based on the four dimensions of social support from [26]. Researchers consisted of lecturers in the fields of education, counseling and early childhood. The research was conducted for a period of six months and involved parents of children enrolled in what is known as a Super Kids program. Before being interviewed, all parents filled in a consent form that agreed to their willingness to become research participants. After being interviewed, all parents filled out a member check to establish the validity of the data.

\subsection{Participants}

Participants were parents of SAR participants aged between 0-6 years old. The study participants consisted of mothers $(n=4)$ and fathers $(n=3)$, some who had a sports education background $(n=4)$ and others who did not have a sports education background $(n=3)$. Participants provided informed consent before data collection. To make it easier to analyze the interview data, the researcher gave code B (Mother) for the mother who was a participant, and code A (Father) for the father who was a participant. While the number 1 indicates the order of the participants, that is, B1 to B4 and A1 to A3.

\subsection{Data Collection}

The data were collected using semi-structured interviews instruments conducted with respondents one on one over a period of around 60 minutes. A grid or interview guide was used, based on social support theory consisting of emotional support, instrumental support, informational support, and companionship support [26]. Participants were asked ten questions relevant to emotional support, eight questions relevant to instrumental support, five questions relevant to informational support and six questions relevant to companionship support. Some parents were willing to be interviewed face-to-face and some only by telephone. Interviews were conducted in the home and at a sports training ground. Documentation in the form of pictures and video recordings of parents talking about their children's sports activities were used as additional data (observation).

\subsection{Data Analysis}

Data analysis began by making a transcript of the interview results, followed by coding to find the focus and sub-focus of parental support. Data analysis in this study used taxonomic analysis.

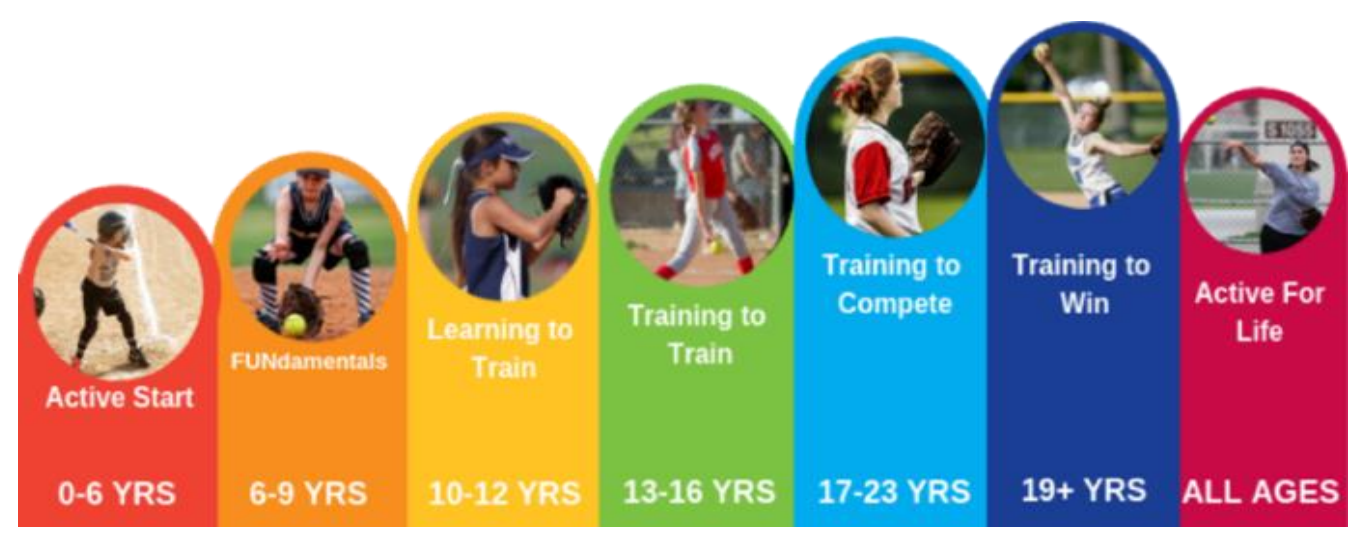

Figure 1. Long Term Athlete Development 


\section{Results and Discussions}

Table 1. Characteristics of Research Participants

\begin{tabular}{|c|c|c|}
\hline Participants & $\begin{array}{c}\text { Frequency } \\
(\mathrm{n}=7)\end{array}$ & $\%$ \\
\hline $\begin{array}{l}\text { Parents' Age } \\
\text { - } \quad \text { Under } 40 \text { years } \\
\text { - } \quad \text { Over } 40 \text { years }\end{array}$ & $\begin{array}{l}6 \\
1\end{array}$ & $\begin{array}{l}85.7 \% \\
14.3 \%\end{array}$ \\
\hline \begin{tabular}{ll}
\multicolumn{2}{l}{ Gender } \\
$-\quad$ Male \\
$-\quad$ Women \\
\end{tabular} & $\begin{array}{l}3 \\
4 \\
\end{array}$ & $\begin{array}{l}42.9 \% \\
57.1 \% \\
\end{array}$ \\
\hline \begin{tabular}{ll}
\multicolumn{2}{l}{ Parents' Education } \\
$-\quad$ Sports \\
$-\quad$ Non-Sports \\
\end{tabular} & $\begin{array}{l}4 \\
3 \\
\end{array}$ & $\begin{array}{l}57.1 \% \\
42.9 \% \\
\end{array}$ \\
\hline $\begin{array}{ll}\text { Parents' Job } \\
\text { - } \quad \text { Sports } \\
\text { - } \quad \text { Non-Sports } \\
\end{array}$ & $\begin{array}{l}4 \\
3 \\
\end{array}$ & $\begin{array}{l}57.1 \% \\
42.9 \% \\
\end{array}$ \\
\hline $\begin{array}{l}\text { Home Distance - Training Place } \\
\text { - } \quad \text { Less than } 2 \mathrm{~km} \\
\text { - } \quad \text { More than } \\
\end{array}$ & $\begin{array}{l}3 \\
4 \\
\end{array}$ & $\begin{array}{l}42.9 \% \\
57.1 \% \\
\end{array}$ \\
\hline
\end{tabular}

The participants of this study were the parents of four children who were members of the Super Kids program. Participants included three couples (father and mother) and one individual parent (mother). Data on the characteristics of participants in this study can be seen in Table 1 which shows that most participants had an educational background and work in sports. Those parents who lived far from training sites, did not seem to be prevented from supporting their children's participation in sports.

\subsection{Reason and Benefit for Joining Sport in the Active Start Period}

Super Kids is a track and field program for children under 6 years of age. The program was developed from a monthly athletic competition that was held for children under 6 years of age.

Not all participants under the age of 6 become members of the Super Kids program. At the time this research was conducted, four children aged between 2.6 and 5 years (two boys and two girls) were members of the Super Kids program. Two participants had older siblings who were previous members of the club whilst the other two children did not have siblings who were members of the club.

Figure 2 shows children participating in the monthly athletic competition, some who can compete independently and others who are helped by the coach to get to the finish line.

Based on Long Term Athlete Development (LTAD) [7], the Super Kids program has what is called an active start period at 0-6 years where children develop rapidly in their physical, motor, cognitive, social and emotional aspects of development. Parents enroll their children as early as possible in the club for the purpose of introducing children to sports, accommodating their physical motor development, and for health factors [1], [2].

“... I really like mobile activities, especially at home, which is so active (A4: 23-24)

"Want to introduce this child to sports ... so that their motor skills can develop even more (A1: 41-42)

“... To sports which form the basic pattern of their movements (B2: 39-40)

“... He sleeps well, makes it easier to talk to him... he doesn't play at random (B1: 21-23)

"She doesn't get sick more easily, is healthier (B4: 211-212)

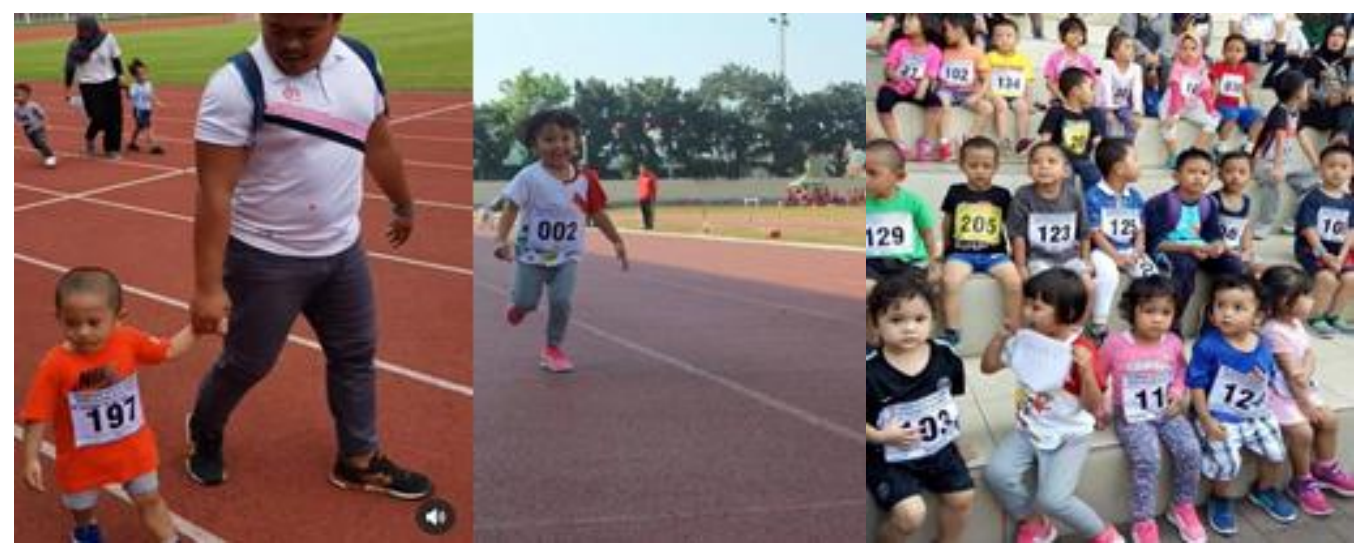

Figure 2. Monthly Athletics Competition for Children Under 6 years of age 
Apart from being related to health and physical motor development, parents also expressed other hopes by encouraging their children to practice sports at the club. Parents want their children to be more social, more self-confident, and more focused. Thus, other aspects of children's development such as cognitive, social and emotional aspects can also develop alongside physical motor aspects [5], [11]. Parents expressed these feelings about their children's involvement in training with the club.

"I don't demand anything from him. In the sense that I do not demand that he be an athlete, I do not demand this, the important thing is that he wants to train, lots of friends (A1: 308-310)

"The point is for socialization ... I want him to understand sports, how to do sports (B4: 70-71)

“... Being taught the main thing is playing... interacting with peers (B2: 41-42),

"So that he is confident (A3: 36)" Now they tend to be more focused (A3: 317)

Based on parent responses, it can be concluded that creating an athlete is not the main reason that parents involve their children in sports during the Active Start period. Through physical activity, parents hope to be able to accommodate children's physical motor development which is considered significant at this early age. Sports activities carried out in the early childhood years can also develop other aspects of development such as cognitive, social, and emotional aspects [1], [3]-[5].

"They also teach children, the attitudes (B1: 205)

"There is character development (A3: 390)

"Not according to the coach's expectations (B1: 224) ... but the coach said," Good Ghaniya, let's continue (B1: 226-227)"

Through sports activities, the Super Kids program not only develops fitness and physical motor skills, but positive character traits can also be developed [33], [34]. Therefore, the role of the trainer is to develop children's character as well as their physical characteristics [33]-[36] through the use of various games. Parents support the trainer in developing positive character traits by reminding their children to respect the coach during the training. Exercise routines that run according to a schedule and following various games that use certain rules are ways that can instill discipline and help shape the character in early-childhood [5], [37].

\subsection{Emotional Social Support for Super Kids}

Emotional or esteem support in this research refers to parental support in the form of feelings of empathy, giving attention, giving positive appreciation and encouragement to their children for practicing or exercising. Emotional support is evident from the ability of parents to empathize or identify the feelings and thoughts of children when practicing sports, as if parents are able to enter the world of training being done by their children. Parents expressed pleasure in watching their children practicing sports and the children were happy because they felt training for sports was the same as playing.

"His son is quite interested. (B1: 172)

"... his movements are active, that means he is happy to be in the field (A4: 100)

“... Seems to enjoy and enjoy (A3: 323)

"He's happy. That's why he can play (B1: 217)

“... Just playing, maybe the mind (A3: 337)

Interview results demonstrate that the form of support provided by parents was in accordance with the needs and characteristics of early childhood where play is oriented to having fun [38]. Parents can function effectively by providing support accompanied by understanding, for example, about children's growth and development and the characteristics of sports coaching [7], [8], [27], [30]. Thus, children can maintain their pleasure and enjoyment in sports, and parental support can be viewed as useful [28], [29].

According to parents' observations, the feeling of pleasure that the child feels is not only shown non-verbally but is also expressed through sentences that the child delivers directly to their parents.

“... They don't get bored until they sometimes add. When are you training again?" (B4: 18-19)

"Happy is the spirit, sometimes he is even more" Come on, Bun, practice "(B3: 75)

"He with enthusiasm with enthusiasm" Papa, I want to exercise "(A1: 270)

In addition to feeling happy, parents were also able to identify when children felt sad, bored, or "cranky" when training.

"When the Coach's attention was not on him, he was ignored, so he immediately became frustrated (B2: 100-101)

“... Crying... sulking, but leaving too (B2: 156-157).

"If just given the movement, he is usually a bit bored (B3: 83-84).

"... sometimes happy, sometimes the mood is different (A4: 52).

Although children were sometimes moody, [39], [40] consider that children must be able to experience sport as something that is fun and makes them happy, therefore, the coaching process should be oriented towards physical literacy. Physical literacy is a concept aimed at individuals 
who are physically intelligent so they can carry out their life activities that require physical activity confidently, competently, effectively, efficiently, and optimally. At the 0-6 age, parents should not treat children as athletes in the true sense, because it will only suppress and ultimately hinder the development and continuation of their sports talents in the future.

Apart from being empathetic, parents showed their emotional support through their attention and active involvement in sports activities carried out by children, such as: escorting and or picking up when children exercise, waiting for children to exercise, paying attention and recording children's activities, and providing sports equipment as needed.

"During training I try not to miss, sometimes I still wear my work clothes (A3: 356-357)

"I have to sit down, approach him, video in him, to be sent to his brother (B4: 158-159)

"When I picked him up, it seemed like a form that was really invaluable to him (A1: 295-296).

“... I gave him equipment that was safe for him (A4: 120)

Parental attention was also shown when they ask about the exercise activity that the child had just finished doing. When parents or families ask questions, children feel that people are interested in them and the sports activities they do.

"... take us, wait, what if, for example, it's finished asking?" What have you been practicing, what are you doing? (B3: 118-119)

"Usually, the grandmother and her age always ask when she finishes training (B4: 460-461)

The positive involvement and support of parents during Active Start phase needs to continue during the Fundamentals coaching phase with the goal that children will continue to maintain their willingness to practice sports [19], [30]. If students maintain their involvement in sports prior to adolescence, parents may be rewarded by discovering their child is gifted in sports [19].
The following observations also show how parents pay attention to their children when they are doing sports.

O2-2a: Mother records Shakila's training activities in the field. The trainer demonstrates the basket carrying motion and the overcoming cone motion. Syakila and one of her friends followed the coach's directions: first, stepping over the cone while each carrying a basket filled with a ball above his head; second, running on the target in front of him; third, putting the ball into the bucket provided (20-21"). Then Syakila and her friend ran and stepped over the cone to return to the starting place (22-32"). There was one trainer who followed beside Syakila and one trainer who followed beside his friend.

O3-4a: Mother recorded when Riyan was practicing at home. Riyan moved her hands while shifting her body from left to right with her prone body not touching the floor. Riyan moved her hand around the puzzle boxes that had been prepared on the floor. Riyan said, "Be photographed first, right?" ( 3 "). After reaching the end of the puzzle box, Riyan stood up and jumped on the spot (10")

Figure 3 shows the children's sports activities recorded by their parents during home and field training.

This research highlights the role of motivation as an important aspect of the emotional support parents give their Super Kids. Motivation is a form of positive appreciation aimed at maintaining enthusiasm for sports activities [19], [30]. Most parents provided motivation in the form of rewards or gifts that children like such as toys, food, drinks, or the opportunity to go out of town.

".. Like once a month he wants to eat anything, every three months we go out of town (B1: 397-398),

"When the match is over, we invite him to walk (Al: 313)

“... I want to practice sometimes I like to say that after training we will buy ice cream (B3: 233-234)

“... Good training. I'll buy something later, Syakila. It's up to you (B2: 110-111) ... for example, barbie, or a pencil holder who is trending (B2: 116)

"Keep on the finish line, bring frills, always bring the fishing rod, it's a toy (A4: 85-86)
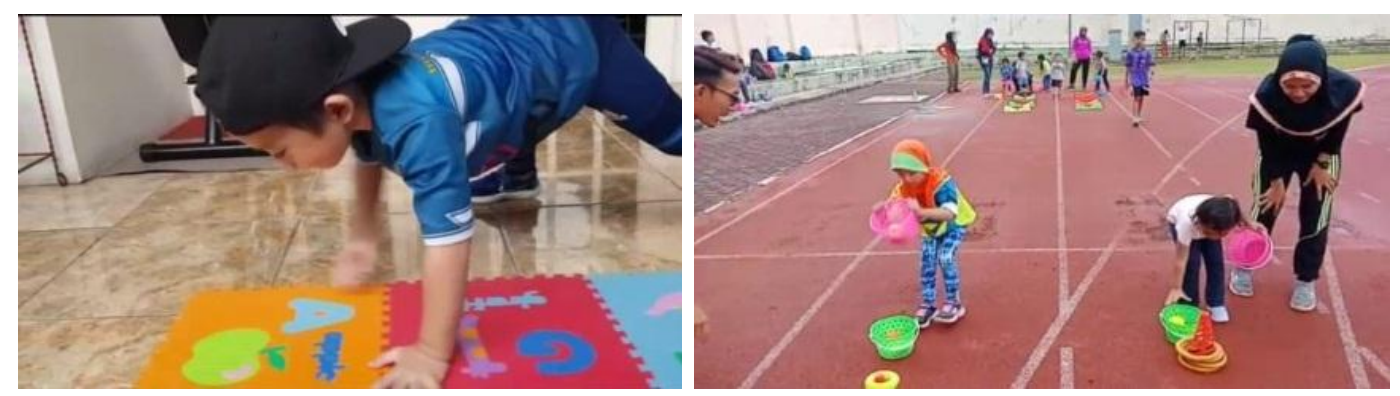

Figure 3. Parents' attention by recording "super kids' sports activities 
Parents in the research agreed that the presence of the father significantly motivated children to be excited about both daily practice and the competitions that take place approximately once a month.

Mothers usually had more time accompanying children to practice sports than fathers. However, this little time was able to provide opportunities for fathers to interact personally with children, so that children feel comfortable in the environment where they are [41], [42]. In this context, family values of parents roles as "good mother" for mother and "super hero" for father [41] play important role. Fathers have the highest relationship when the child's ability or effort is at a low level [28]

"Motivation, .." I'll pick you up to this afternoon "(B1: 93-94)

"I'm really happy to be different if my father delivers him (B2: 306). He has energy ... he is more "it's my father" (B2: 311-312)

"Abi is my idol (B4: 131)

"Come on, son, Dad, wait ... Daddy, wait in front of the finish line (A3: 298)

Other than those mentioned above, parents of Super Kids provided other forms of motivation to encourage their children to be excited about sports activities. They followed the child's movements [43] using music, giving advice, and shouting motivational words accompanied by certain body language [44], that included others outside the nuclear family during competitions [22], [23].

"I joined the movement too (A1: 121)

"I can make him move at home, accompany him (Al: 170-171)
"... If he practices at home by himself, he must use music (B4: 213-214)

"I have to be enthusiastic. I can do it., I don't need to be a champion, but the important thing is that I want to do it. I see, so if I can, it means I have won (A4: 148-149)

“... Just raise your hands up, mom... Cheer up .. come on (A3: 311-312).

"Sometimes I come to him to give him support during the match (A1: 318-319).

Observations below show how parents pay attention to their children when they are doing sports.

O1-2a: While following her brother doing the jumping jacks, Ghaniya complained "aaah can not" (5 "and 20"). Mother said, "Slow Adek, come on it's okay ... come on, come on" (13-15") Despite stopping, Ghaniya wants to move back and try doing jumping jacks again (16-19")

Figure 4 shows children doing sports activities while being given verbal encouragement by parents. The motivational sentences below were recorded by parents during home training and during competitions.

O3-3a: During the match, Father was seen shouting repeatedly when Riyan started running from the starting line: "Aa... Aa... Aa... run running" (1-6" and 7-10") Riyan seemed to focus on running with a forward gaze at his father who was waiting at the finish line. Riyan ran within her track from start to finish.

O4-2a: Daddy records while waiting at the finish line as Arka enters the monthly race. When Arka started running, my father encouraged him: "Come on.... Come on can run.... Come on"(1-6")
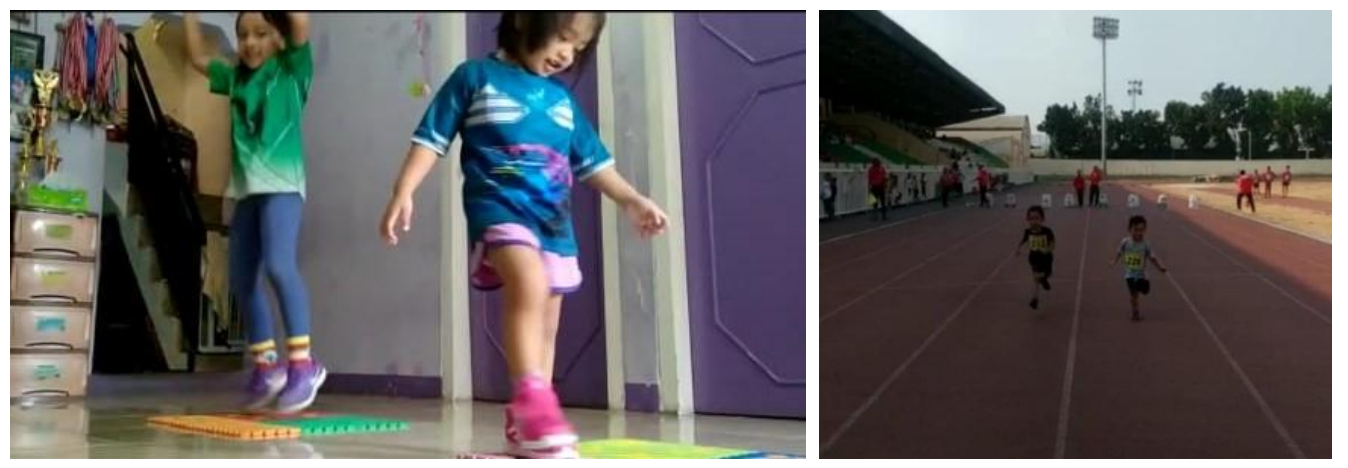

Figure 4. Parents' motivational sentences to encourage children during training and competitions 


\subsection{Instrumental Social Support for Super Kids}

Tangible or instrumental social support in this study is represented by parents providing material or financial support in order to meet the needs of children practicing sports. Parents indicated they had no objection to the monthly fees or other fees paid to the club. Parents provided equipment such as sports shoes, clothes and exercise support equipment that could be used at home for their children to practice daily [22[, [23].

"The cost of training at the club is actually quite cheap (B1: 104).

\section{"It's still affordable for training costs (B3: 175)}

"... from the things that must be fulfilled, yes, shoes ... shoes and clothes are what you wear every day (B2: 189-190)

"We give him facilities like proper clothes, maybe it's a spirit for him (A1: 153-154)

All parents must provide basic and simple tools such as cones, markers, cadres and balls. One parent made a simple modification with origami paper for the child to practice squatting at home.

"The marker, cone, ladder is there I continue for small balls (A1: 197)

“... At home, there are cones and football (A3: 408-409)

"Markers or cones, then there are cadres, now that's enough. I think there is a plastic ball for him to throw the target (A4: 212-213)
O2-3b: Mother provides the means for Syakila to practice squeezing at home. Mother placed a straight line in front of Syakila five HVS papers whose origami paper had been attached in the middle in the order of colors: red, orange, yellow, blue, and red. Syakila squatted with her right foot three times, then used her left leg twice, and her right foot once again arrived at the last paper sequence (1-3"). Syakila smiled cheerfully when she reached the finish (3"), even though her steps were not exactly in the middle of the colorful box from origami earlier.

The ready-to-use (ball or cone) or modified equipment provided by parents at home is shown in Figure 5.

Some parents deliberately set aside money specifically to buy additional sports equipment needed for their children. The additional equipment for children's sports activity is expected to support the development of motor movements such as a bicycle without pedals (balance bike), trampoline, and others. Parents invite their children to enjoy visiting sports shops.

“... We have extra money. We take it to the sports shop (B1: 186-187)

"I bought a toy that helps his motor skills (B2: 194-195)

“... With Abi bought a balance bike. He wanted to ride it, run fast (B63-64)

"The swimsuit is specifically for the children, so it's not just the pants, but the full body set (A4: 195-196)

"I facilitated" where to go, we go to decathlon. We buy hopping "so finally I bought a trampoline, (A4: 322-323)
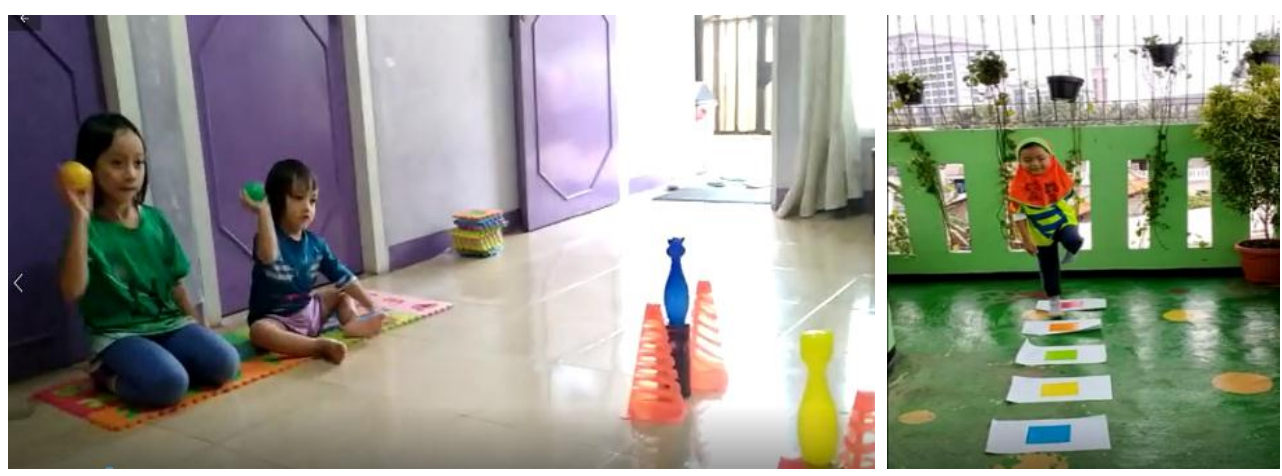

Figure 5. Parents provide simple exercise equipment at home 
O4-1b: Riyan uses a balance bike (bicycle without saddle) that his father bought, complete with a helmet. Riyan runs his bicycle by alternating his feet. Father said to Riyan "Chase the horse A '(14"), then Riyan followed suit by speeding up his footsteps while occasionally looking down.

Figure 6 shows the swimming equipment and balance bike purchased by parents for their children's sports activities

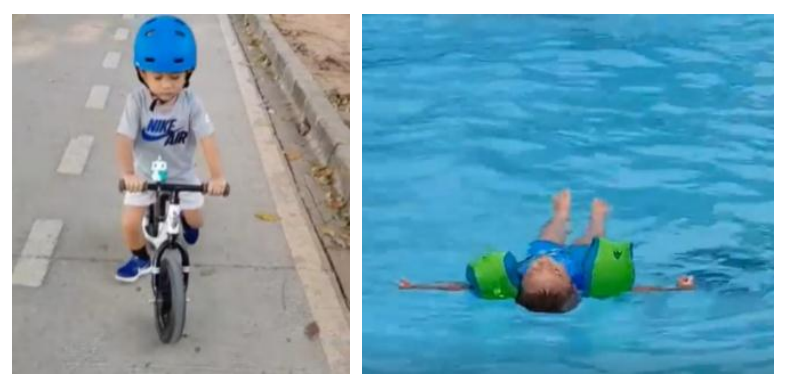

Figure 6. Balance bike and swimming equipment from parents

In addition to providing exercise equipment, parents also play a role in meeting the nutritional needs of the Super Kids [19], [23], [27]. Milk was provided by the parents every day.

That night I must give milk (B2: 240)

They also consume milk (A1: 227)

Drink formula milk (A3: 419)

He still consumes $S 26$ milk (A4: 224) ... a day can be 8 bottles to 10 (A4: 247-248)

Some parents provided vitamins, and some provided honey as an additional supplement.

In the morning, I'll give him extra vitamins (B2: 238)

Vitamin is always yes (B3: 225).

Best provided the honey he likes (B4: 315-316)

I provide honey (A1: 262)

The children were encouraged to eat vegetables and protein sources such as eggs, fish, tofu and tempeh and parents prepared nutritious food for their children. One child appeared to be a "picky" eater and only wanted to eat if his father ate the side-dishes.

If prepared to eat with vegetables, he eats quickly (B2: 219-220)

Soup, spinach, he likes boiled eggs the most (B3: 201).

Vegetables, fish, tofu, tempeh must be available every day (A1: 225 .

His brother eats fish. He's interested in it, then he wants to (B4: 323)

Based on interview data, it can be concluded that instrumental support took the form of a financial investment by parents to support their children's activities such as training or monthly fees and equipment. Parents also fulfilled their children's nutritional needs to support the daily sports activities. Parents were willing to make financial sacrifices, thereby generating appreciation from children as recipients of the support [24].

\subsection{Informational Social Support for Super Kids}

Informational social support in this study refers to the advice, directions, and feedback given by parents to their child [26]. Super Kids who are still at an early age did not always understand the instructions given by the trainer, so parents helped by repeating instructions for the sequences of movements to be done, and demonstrating or giving examples that children could see directly [43], [44].

“... He doesn't immediately understand what the instructions are, so we just help instruct (B1: 302-303) ... give the code (B1: 306)

"SI just gave him support. So the important thing is that you just run, you don't need to think about anything, you don't need to look to the right or left (A1: 65-66)

"... give knowledge to him, the sequence (A4: 112-113),

"Stretching like this is the form of movement (B1: 312)

“... Give him the kind of move (B2: 251)

"... the movement to do movements, imitate (B3: 155)

In addition to directions related to the movement activities, parents also provided direction or advice related to attitudes, for example, the attitude of being serious and focused during training and the attitude of showing respect for the coach. Parents' attitudes reflect family values and become the main source for building character in early-childhood [35], [36]. Parents provide examples of attitudes and behaviors as well as the social skills that will support them when facing competition [43].

"... together with father, it is said that the exercise must be focused, it must be serious (B4: 233-234),

"If training, you have to concentrate on what the coach says (B4: 427-428)

"Dedek must always listen to the coach's words, don't upset the coach (A1: 139-140)

"The direction is not a direction like a coach to an athlete, but the direction is an important direction for him to do the movement (A1: 95-96)

Informational support from parents also takes the form of feedback to children [23], [44]. Parents provided feedback by asking children questions about the exercise program. These questions are asked in a relaxed atmosphere at home, or indirectly over the phone. Parents provided feedback on the program exercises by asking questions or making small talk in a relaxed atmosphere at home with the researchers. 
"... after training I will ask again (B3: 92)

"After training, I called her brother, then at night he was invited to chat (B4: 444-445)

"I asked," What was the deck doing? " (A1: 128)

"... I asked, "how was the training... okay, tomorrow you have to get better, huh? (A4: 299-300)

Parents also reflected on or evaluated sports training activities carried out by their children by providing additional explanations for improving children's future performance. In this instance, parents acted as teachers by providing direction and guidance [44].

"At home we explain what the coach really means (B1: 335)

"Do not move half-heartedly for Syakila, it's okay if you just pull her hand, don't run slowly (B2: 279-280)

“... What reflection did he do (A3: 183)

"... we talk, give feedback, give evaluation (A4: 313-314)
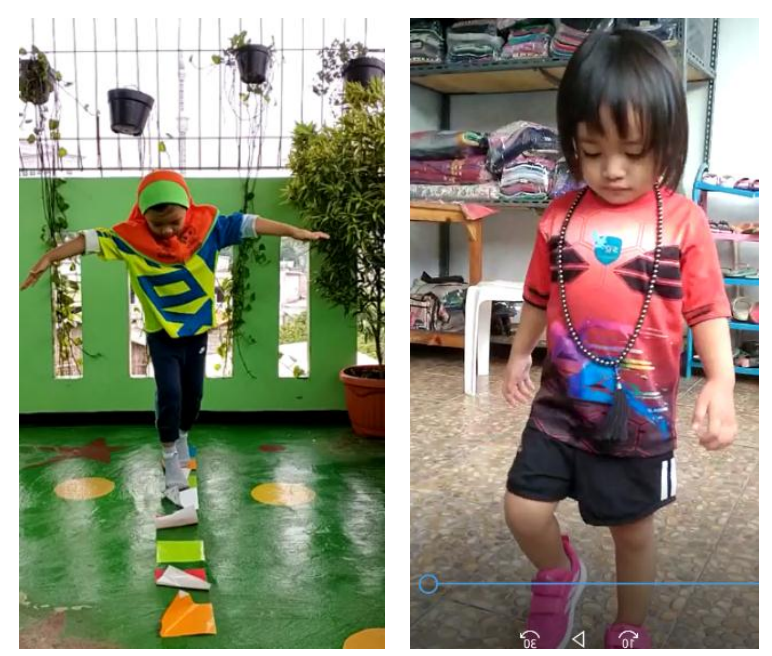

Figure 7. Support in the form of directions or instructions from parents

Informational support in the form of giving directions and providing feedback shows indirect parental involvement in sports activities carried out by their child. This type of feedback aims to improve the performance or movements that the child does [28], [44]. The observations below relate to informational support provided by parents during the program:

O1-1c: During home training, Dad gave instructions to Ghaniya to run on the spot following his brother. Ghaniya had just run in place during the third instruction (47-50"). The rest she was back and forth from where she was running to where her brother was. Father also gave other instructions such as: "Swing his hand!" or "Lift his knees like a big brother!" (52-56")

O1-4c: Father gives instructions to run in place in the form of counting (one, two, three, four, five), Ghaniya follows instructions until only the count of four (1-6").
Mother also reminded "Your hand, son" (12 "). Shown in figure 7 on the left

O2-4c: Mother instructed Syakila to walk while looking forward: "Look ahead son, look ahead!" However, Syakila was still walking while looking down, she tried to walk right on top of every colorful origami paper taped to the floor (1-4 "). Shown in figure 7 on the right.

\subsection{Companionship Social Support for Super Kids}

In this study, Companionship Social Support is provided by parents through their willingness to accompany or spend time with their child during sports activities. In the club program, mothers mainly accompanied their child. If they were unable to do so, they found a replacement to accompanying the child to practice. One father in the program always accompanied his child to training and other fathers reported that they were trying to pick their child up from training at suitable times.

"I full accompany the child (B1: 329)

"Sometimes I hang out (B2: 69) sometimes with my uncle (B2: 80-81)

“... I practice 2 times a week, so I take the time to go home early (A3: 42-43)

“... I will deliver, continue to wait for his father (B3: 49-50)

“... I didn't accompany them but picked them up after training (Al: 53)

At competition time, almost all parents accompanied their child which sometimes meant reorganizing work duties. A parent's presence during competition relates to providing emotional support through using motivational language, body language, and providing rewards for the child before and after competing [23], [43], [44].

Parents of Super Kids provided companionship by accompanying their children to training and competitions, especially when their child entered a race where emotional involvement and support was considered essential [29], [44]. Parents make judgments about the various ways they can support their child by finding the most appropriate way to motivate and suit the needs of each child [22], [31], [44].

"... I accompanied the two of us more often during the competition (B3: 103-104).

"When I was playing, I accompanied him because I was always on the weekend (A1: 55-56).

"Always accompany (when competing) (A3: 39)

“... The competition continues (accompanying) (A4: $85)$

"I love him, support him" Come on. Syakila is enthusiastic "(B2: 288)

Figure 8 shows parents accompanying children when they participate in monthly athletic competitions. 

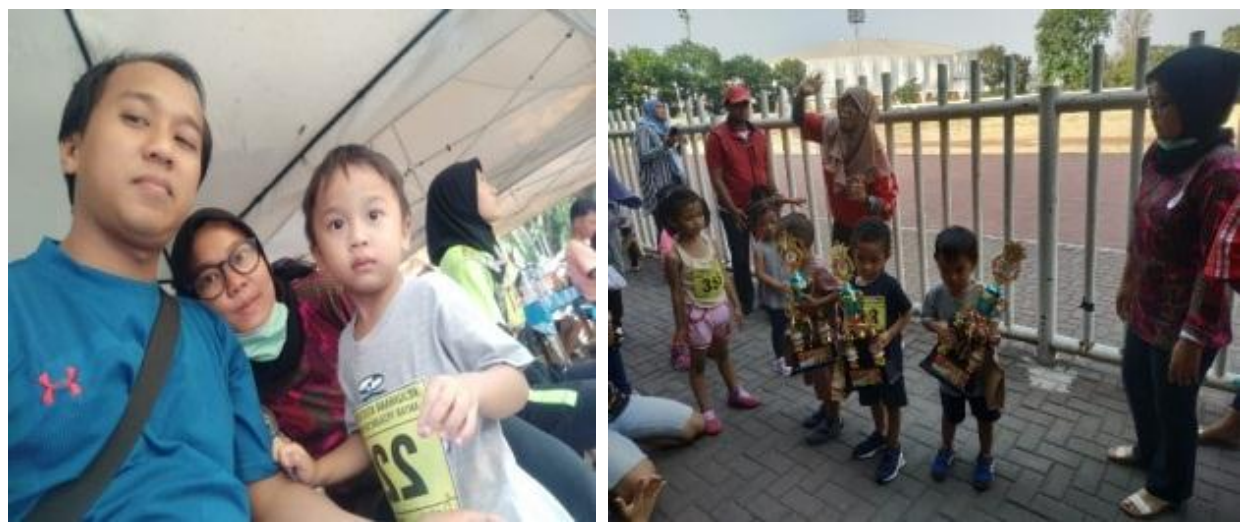

Figure 8. Parents accompanying children while participating in a competition
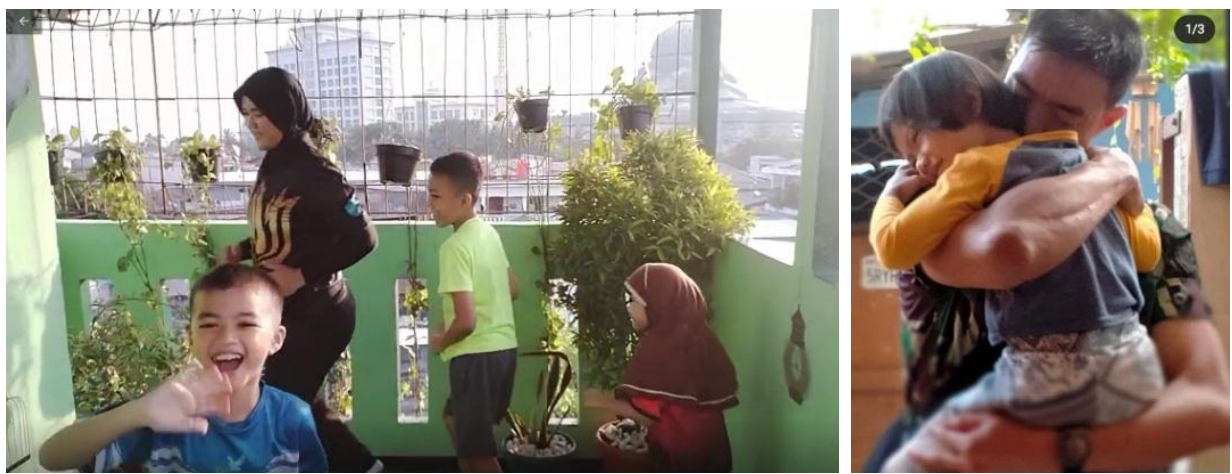

Figure 9. Parents encourage children to practice at home

Some parents encouraged their child to do additional exercises at home and other parents did not [33], [39].

"Sometimes I like exercising, together, jogging and going around the existing place (B2: 299-300)

“... I take them from time to time (to practice at home) (A1: 79)

O2-1d: Bunda accompanied Syakila and her two brothers to run on the roof of the house. Mother leads the run in the front row (1-4"). Mom then ran in the second row, behind one of Syakila's older siblings (5-12"). Then mom takes turns again, leading the way in the front row again (15-18")

Some Super Kids did other sports activities outside of training hours aimed at supporting their training in SAR, while exercises done at home were repetitions of exercises carried out during training [34], [35].

"In addition to the basic movement activities which are athletic ability, I also invite them to cycle and swim (A4: 47-48)

“... At home... what kind of practice yesterday let's repeat (B3: 120)

“... Later corrected the wrong father (B1: 355-356).

“... I don't want to force it. If he looks bored, then we are done (A1: 91-92)

"I love the color reaction game ... give him a balance training exercise (B2: 212-213)

Figure 9 shows a mother accompanying their child jogging at home, while the father hugs the child after practice.

Parents reported that they provided support by being willing to accompany their child either during routine training twice a week or during monthly competitions. Some parents encouraged their child to exercise at home or to do other sports that supported their training such as cycling or swimming.

\subsection{Background of Parents and Their Kind of Social Support}

Data analysis indicated that there was no significant difference between the emotional support provided by either mothers or fathers to their children in the club program. Both fathers and mothers empathized, gave attention, and motivated their child. Both parents identified their child's emotions, including when they were feeling sad. Fathers and mothers appeared to share the role of providing motivation according to the child's needs [19], [44] regardless of their background in education and/or sport.

A comparison of emotional social support from parents with sports and non-sports backgrounds is shown in table 2 below: 
Table 2. Comparison of Parents' Emotional Social Support

\begin{tabular}{|c|c|}
\hline Mother & Father \\
\hline $\begin{array}{c}\text { "His son is quite interested. (B1: } \\
172)\end{array}$ & $\begin{array}{l}\text { “... interest enough, yes } \\
\text { enough interest (A1: 85) }\end{array}$ \\
\hline Description: NON-SPORT & Description: SPORT \\
\hline $\begin{array}{l}\text { "... crying ... sulking, but leaving } \\
\text { too }(\text { B2: 156-157) }\end{array}$ & $\begin{array}{l}\text { "(If you don't win) it looks } \\
\text { sad ... But the sadness doesn't } \\
\text { drag on (A3: 291-292) }\end{array}$ \\
\hline Description: & Description: NON-SPORT \\
\hline $\begin{array}{c}\text { "I have to sit down, approach him, } \\
\text { take video on him, to be sent to his } \\
\text { brother (B4: 158-159) }\end{array}$ & $\begin{array}{l}\text { "There is also a YouTube } \\
\text { channel (A4: 218) }\end{array}$ \\
\hline Description: NON-SPORT & Description: SPORT \\
\hline $\begin{array}{c}\text { "It will make you more } \\
\text { enthusiastic if you are } \\
\text { accompanied by your parents (B3: } \\
248-249) \text {. } \\
\text { Description: SPORT }\end{array}$ & $\begin{array}{c}\text { "... just raise your hands up, } \\
\text { mom ... Cheer up .. come on } \\
\text { (A3: 311-312). } \\
\text { Description: NON-SPORT }\end{array}$ \\
\hline
\end{tabular}

In providing instrumental social support for their child there appeared to be no significant difference between mothers and fathers even though they might take different roles [19], [23]. For example, with regards to costs and equipment, the father seemed to have a greater role in providing materials or financial support while the mother prepared nutritious food. Both parents agreed to and supported these roles.

A comparison of instrumental social support from parents with sports and non-sports backgrounds is shown in table 3 below:

Table 3. Comparison of Parents' Providing Instrumental Social Support

\begin{tabular}{|c|c|}
\hline Mother & Father \\
\hline $\begin{array}{c}\text { "The cost of training at the club } \\
\text { is actually quite cheap (B1: } \\
\text { 104). }\end{array}$ & $\begin{array}{l}\text { "The training fee for me is not } \\
\text { too expensive (A1: 175) }\end{array}$ \\
\hline Description: NON-SPORT & Description: SPORT \\
\hline $\begin{array}{l}\text { "... swim come on, I'll look for } \\
\text { the swimsuit (B4: 263) }\end{array}$ & $\begin{array}{c}\text { "... the swimsuit, especially for } \\
\text { the children, so it's not just the } \\
\text { pants, but the full body set (A4: } \\
\text { 195-196), } \\
\text { Description: SPORT }\end{array}$ \\
\hline $\begin{array}{c}\text { "... there must be green } \\
\text { vegetables, in that house every } \\
\text { day, there are vegetables ... I } \\
\text { cooked tofu and tempeh, it's } \\
\text { already dry, so the fish will } \\
\text { automatically have sauce (B1: } \\
121-124)\end{array}$ & $\begin{array}{c}\text { “... my wife paid enough } \\
\text { attention to food problems (A1: } \\
220)\end{array}$ \\
\hline Description: NON-SPORT & Description: SPORT \\
\hline $\begin{array}{l}\text { "Vitamin is always yes (B3: } \\
\text { 225). } \\
\text { Description: SPORT }\end{array}$ & $\begin{array}{l}\text { "... that vitamin is also from } \\
\text { Kalbe (A3: 424) } \\
\text { Description: NON-SPORT }\end{array}$ \\
\hline
\end{tabular}

Parents with an educational background and/or who worked in the sports sector usually had access to simple equipment for their child to use such as cones, cadres, and colorful plastic balls which they already used in their daily work. Because of their experience in the field of sports, they could provide appropriate support for their child's needs [29], [30], [38].

“... the marker, cone, ladder is there for me to keep small balls (A1: 197)

"... markers or cones, then there is a ladder, now that's enough. I think there is a plastic ball for him to throw the target (A4: 212-213)

Description: SPORT

"... At home, there are cones and balls (A3: 408-409)

\section{Description: NON-SPORT}

Research results show that all parents of Super Kids provided informational social support such as directions or instructions that directly related to movements and/or to attitudes or character development during sports practice [23], [43], [44]. Regardless of educational or sporting background all parents provided feedback on the sports activities carried out by their child. For example, a parent with an educational and sports background said: "I asked," What was the deck doing? " (A1: 128), while parents who did not have an educational background and work in sports said: “... we talk, give feedback, give evaluation (A4: 313-314). However, fathers or mothers with an educational and/or sporting backgrounds were more confident in providing examples of movements. They also provided clearer and more detailed feedback because they understood the concept of motion in sports. Parents from educational backgrounds and who worked sports appeared to be more capable of providing informational support. According to [22], [30] these parents look confident and provide detailed directions because they have previous exercise experience. A comparison of informational social support from parents with sports and non-sports backgrounds is shown in table 4 below:

Table 4. Comparison of Parents' Providing Informational Social Support

\begin{tabular}{|c|c|}
\hline Sports & Non-Sports \\
\hline $\begin{array}{l}\text { “... give him the kind of move } \\
\text { (B2: } 251) \\
\text { "... the movement of doing } \\
\text { movements, imitating (B3: } 155) \\
\text { "... give knowledge to him this is } \\
\text { the sequence (A4: } 112-113)\end{array}$ & $\begin{array}{l}\text { "... Stretching like this is the } \\
\text { form of movement (B1: } 312)\end{array}$ \\
\hline $\begin{array}{l}\text { "Dedek must always listen to the } \\
\text { coach's words, don't upset the } \\
\text { coach (A1:139-140) }\end{array}$ & $\begin{array}{l}\text { "... if you practice you have to } \\
\text { concentrate on what the coach } \\
\text { says (B4: } 427-428)\end{array}$ \\
\hline $\begin{array}{l}\text { "Do not move half-heartedly for } \\
\text { Syakila, it's okay if you just pull } \\
\text { her hand, don't run slowly (B2: } \\
279-280) \\
\text { "Swing his hands ... raise his } \\
\text { knees like a big brother" } \\
\text { (O1-1c) }\end{array}$ & $\begin{array}{l}\text { "There's more progress ... zig } \\
\text { zag training, he's confused, at } \\
\text { first. He can't even skip it for a } \\
\text { long time (B3: 164-165) } \\
\text { "Her hand, son" }(O 1-4 c) \\
\text { "Not so many feet ..." (O4-5c) }\end{array}$ \\
\hline
\end{tabular}

Figure 10 shows the parents who were always by the child's side when they were participating in competitions. Fathers or mothers from sports and non-sports backgrounds both accompanied their child during the monthly athletic competitions. 

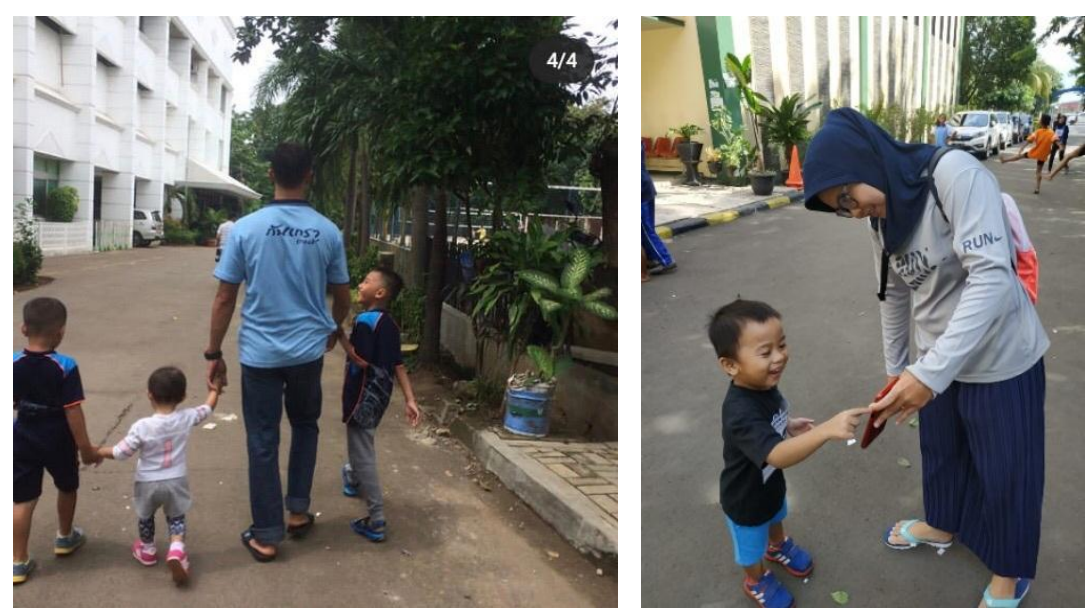

Figure 10. The presence of parents when the children participate in competitions

The willingness of parents to spend time with their children to accompany them to practice sports depended on the compatibility of their free time with their child's training time [23], [44]. For example, all parents could attend competitions because they were held on weekends.

The roles of the two genders were complementary [42] which suggests that the father and mother were highly motivated to support their children to exercise and to encourage them to continue to elite sports at a later date [8], [29], [45].

Table 5 shows social support through companionship from parents with a work or educational background in sports and non-sports. The summary of table 5 shows that there is no difference between the support provided by the father and mother if both parents have an educational background and/or work in sports or who do not have educational experience and/or work in the sport field.

Table 5. Comparison of Parents' Companionship Social Support

\begin{tabular}{|c|c|}
\hline Mother & Father \\
\hline $\begin{array}{l}\text { "Full accompany if I (B1: 329) } \\
\text { Description: NON-SPORT }\end{array}$ & $\begin{array}{c}\text { “...I didn't accompany them but } \\
\text { picked them up after training } \\
\text { (Al: 53) } \\
\text { Description: SPORT }\end{array}$ \\
\hline $\begin{array}{l}\text { "Sometimes I hang around } \\
\text { (B2: 69) } \\
\text { Description: SPORT }\end{array}$ & $\begin{array}{l}\text { "... I practice twice a week, so I } \\
\text { take the time to go home early } \\
\text { (A3:42-43) } \\
\text { Description: NON-SPORT }\end{array}$ \\
\hline $\begin{array}{c}\text { "... I accompanied him more } \\
\text { often during the competition } \\
\text { (B3: 103-104). } \\
\text { Description: SPORT }\end{array}$ & $\begin{array}{c}\text { "Always accompany (when } \\
\text { competing) (A3: 39) } \\
\text { Description: NON-SPORT }\end{array}$ \\
\hline $\begin{array}{l}\text { "Full accompany if I (B1: 329) } \\
\text { Description: NON-SPORT }\end{array}$ & $\begin{array}{l}\text { "... I joined the team during the } \\
\text { match because the match was } \\
\text { always on the weekend (A1: } \\
55-56) \\
\text { Description: SPORT }\end{array}$ \\
\hline
\end{tabular}

Research similar to this study measured emotional support for children in sports programs. In this study, parental support was measured in terms of instrumental support, informational support, and companionship support that can simultaneously reflect emotional support. For example, when parents buy exercise equipment, provide useful directions, and accompany them during training or competitions, parents are providing emotional support for their child. Alongside physical involvement, parental involvement includes emotional involvement where the parents "fully enter" into the world of the child or into their sports activities [44]. Motivational words parents often used were, "come on!". These words encouraged children to be active [23], [43], [44].

This study found that there was no significant difference between maternal and paternal support in terms of each type of support [26]. The mother and father complemented each other and shared roles [19], [28]. For example, the mother might take the child to training and the father pick them up, or the mother might provide nutritious food with the knowledge of the father.

\section{Conclusions}

The study concluded that parents provide all four forms of social support to children who practice sports from an early age of 0-6 years (emotional support, instrumental support, information support, and companionship support). However, there was no difference between the amount of support from the father or mother. Additional information from this research is that parents who had educational background and/or work in jobs associated with sport were more confident in providing detailed informational support. This is an inspiration and a reminder for parents and sports organizers that parents are an important factor in developing early childhood sports talent.

\section{Acknowledgements}

We would like to thank to Universitas Negeri Jakarta and Sekolah Atletik Rawamangun (SAR) for their support. 


\section{REFERENCES}

[1] J. E. Donnelly et al., "Physical activity, fitness, cognitive function, and academic achievement in children: A systematic review," Med. Sci. Sports Exerc., vol. 48, no. 6, pp. 1197-1222, 2016.

[2] V. Carson et al., "Systematic review of the relationships between physical activity and health indicators in the early years (0-4 years)," BMC Public Health, vol. 17, no. Suppl 5, 2017.

[3] J. M. Iverson, "Developing language in a developing body: The relationship between motor development and language development," J. Child Lang., vol. 37, no. 2, pp. 229-261, 2010 .

[4] M. V Wang, R. Lekhal, L. E. Aaro, A. Holte, and S. Schjolberg, "The developmental relationship between language and motor performance from 3 to 5 years of age: a prospective longitudinal population study," BMC Psychol., vol. 2 , no. 1, 2014.

[5] M. S. Sumantri and T. Endrawati, "Kemampuan Sosialisasi Dan Gerak Manipulatif Berbasis Kelompok Pada Anak Usia 4-5 Tahu," Jiv, vol. 8, no. 2, pp. 104-110, 2013.

[6] A.-L. Kyhala, J. Reunamo, and H. Ruismaki, "Preschool Children are More Physically Active and Less Sedentary on Weekdays Compared with Weekends," J. Early Child. Educ. Res., vol. 7, no. 1, pp. 100-126, 2018.

[7] J. Fraser-Thomas and P. Safai, "Tykes and 'Timbits': A critical examination of organized sport programs for preschoolers," Sport Phys. Act. Across Lifesp. Crit. Perspect., pp. 93-116, 2017.

[8] K. Till and J. Baker, "Challenges and [Possible] Solutions to Optimizing Talent Identification and Development in Sport," Front. Psychol., vol. 11, no. April, pp. 1-14, 2020.

[9] V. Unnithan et al., "Talent identification in youth soccer Talent identification in youth soccer," vol. 0414, no. November, 2017.

[10] J. Fernández Río and A. Méndez-Giménez, "Talent detection and development in soccer: a review.," J. Sport Heal. Res., vol. 6 , no. 1 , pp. 7-18, 2014.

[11] M. Buekers, P. Borry, and P. Rowe, "Talent in sports. Some reflections about the search for future champions," Mov. Sport. Sci. - Sci. Mot., no. 88, pp. 3-12, 2015.

[12] M. J. Reeves, A. P. McRobert, M. A. Littlewood, and S. J. Roberts, "A scoping review of the potential sociological predictors of talent in junior-elite football: 2000-2016," Soccer Soc., vol. 19, no. 8, pp. 1085-1105, 2018.

[13] S. Mazid, "Hubungan Antara Kunjungan Orang Tua Ke Pos Pelayanan Terpadu Dengan Perkembangan Anak Usia 36 Minggu," Surakarta, 2015.

[14] E. Edy, M. CH, M. S. Sumantri, and E. Yetti, "Pengaruh Keterlibatan Orangtua Dan Pola Asuh Terhadap Disiplin Anak," JPUD - J. Pendidik. Usia Dini, vol. 12, no. 2, pp. 221-230, 2018.
[15] H. Ibrahim, "Pengaruh bimbingan dan pola asuh orangtua terhadap kemandirian,” 2019.

[16] D. P. Harahap and W. Martani, "Pelatihan Rumah Ramah Literasi untuk Meningkatkan Keterampilan Stimulasi Literasi pada Orang Tua," Gadjah Mada J. Prof. Psychol., vol. 4, no. 2, p. 137, 2019.

[17] E. S. Turnip, R. Kurnia, and D. Chairilsyah, "Analisis Pelaksanaan Kegiatan Kemitraan Orangtua Dengan Sekolah Di TK Negeri Pembina Kota Pekanbaru," J. Pendidik. Tambusai, vol. 3, no. 6, pp. 1598-1604, 2019.

[18] A. Baxter-Jones and N. Maffulli, "Parental Influence On Elite Young Athlete.pdf," J. Sport. Med. Phys. Fit., p. 250, 2003.

[19] J. Cote, "The Influence of the Family in the Development of Talent in Sport," J. Sport Psychol., vol. 13, pp. 395-417, 1999.

[20] T. K. Scanlan, G. M. Chow, C. Sousa, L. A. Scanlan, and C. A. Knifsend, "The development of the Sport Commitment Questionnaire-2 (English version)," Psychol. Sport Exerc., vol. 22, pp. 233-246, 2016.

[21] M. B. Karnes and L. J. Johnson, "Early Identification and Programming for Young Gifted/Talented Handicapped," Topics Early Child. Spec. Educ., vol. 6, no. 1, pp. 50-61, 1986.

[22] K. Lindstrom Bremer, "Parental Involvement, Pressure, and Support in Youth Sport: A Narrative Literature Review," $J$. Fam. Theory Rev., vol. 4, no. 3, pp. 235-248, 2012.

[23]I. Verawati, "Dukungan Sosial Orangtua Dalam Mengikutsertakan Anaknya Berlatih Di Krakatau Taekwondo Klub Medan," EduTech J. Ilmu Pendidik. dan Ilmu Sos., vol. 3, no. 2, pp. 22-28, 2017.

[24] J. Shakespeare-Finch and P. L. Obst, "The development of the 2-way social support scale: A measure of giving and receiving emotional and instrumental support," J. Pers. Assess., vol. 93, no. 5, pp. 483-490, 2011.

[25] T. K. Scanlan, P. J. Carpenter, G. W. Schmidt, J. P. Simons, and B. Keeler, "The Sport Commitment Model," J. Sport Exerc. Psychol., vol. 3, no. 1, pp. 90-99, 1993.

[26]E. P. Sarafino and T. W. Smith, Health Psychology: Biopsychosocial Interaction, Seventh Ed. Danvers: USA: John Wiley \& Sons, Inc, 2011.

[27] A. P. Vincent and D. A. Christensen, "Conversations With Parents: A Collaborative Sport Psychology Program for Parents in Youth Sport," J. Sport Psychol. Action, vol. 6, no. 2, pp. 73-85, 2015.

[28] P. M. Averill and T. G. Power, "Parental Attitudes and Children's Experiences in Soccer Correlates of Effort and Enjoyment.pdf," Int. J. Behav. Dev., vol. 18, no. 2, pp. 263 276, 1995.

[29] M. Siekańska, “Athletes’ perception of parental support and its influence on sports accomplishments - A retrospective study," Hum. Mov., vol. 13, no. 4, pp. 380-387, 2012.

[30] C. J. Knight, T. E. Dorsch, K. V. Osai, K. L. Haderlie, and P. A. Sellars, "Influences on parental involvement in youth sport," Sport. Exerc. Perform. Psychol., vol. 5, no. 2, pp. 161-178, 2016. 
[31] D. Armi, Mansur, and M. Nusufi, "Partisipasi Orang Tua Terhadap Minat Anak Berolahraga di Kecamatan Singkil Kabupaten Aceh Singkil," J. Ilm. Mhs. Pendidik. Jasmani, Kesehat. dan Rekreasi, Fak. Kegur. dan Ilmu Pendidik. Unsyiah, vol. 4, pp. 258-271, 2015.

[32] S. Barefield and S. McCallister, "Social support in the athletic training room: Athletes' expectations of staff and student athletic trainers," J. Athl. Train., vol. 32, no. 4, pp. 333-338, 1997.

[33] Bafirman, "Relationship of Character and Physical Fitness Quality through 'Penjasorkes' Learning to Students of Elementry School," Int. J. Humanit. Soc. Sci., vol. 4, no. 11, pp. 198-204, 2014.

[34]Hariadi, "Pengembangan Pendidikan Karakter Dalam Pendidikan Jasmani dan Olahraga Pada Pendidikan Anak Usia Dini," Parameter, vol. 24, no. 1, pp. 13-26, 2014.

[35] D. Prasanti and D. R. Fitriani, "Pembentukan Karakter Anak Usia Dini: Keluarga, Sekolah, Dan Komunitas? (Studi Kualitatif tentang Pembentukan Karakter Anak Usia Dini Melalui Keluarga, Sekolah, dan Komunitas)," J. Obs. J. Pendidik. Anak Usia Dini, vol. 2, no. 1, p. 13, 2018.

[36] J. Siswanta, "Pengembangan Karakter Kepribadian Anak Usia Dini (Studi Pada PAUD Islam Terpadu Di Kabupaten Magelang Tahun 2015)," Inferensi, vol. 11, no. 1, p. 97, 2017.

[37] I. Noffia and M. S. Yuliariatiningsih, "Mengembangkan Disiplin Anak Usia Dini Melalui Permainan Tradisional," Cakrawala Dini J. Pendidik. Anak Usia Dini, vol. 6, no. 2, pp. 112-120, 2018.
[38] S. Park and S. Kim, "Parents' perspectives and young athletes' perceptions of social support," J. Exerc. Rehabil., vol. 10, no. 2, pp. 118-123, 2014.

[39] S. Silverman and K. Mercier, "Teaching for physical literacy: Implications to instructional design and PETE," J. Sport Heal. Sci., vol. 4, no. 2, pp. 150-155, 2015.

[40] M. Whitehead, "The Concept of Physical Literacy," Eur. J. Phys. Educ., vol. 6, no. 2, pp. 127-138, 2001.

[41] R. V. Bullough, "Differences? Similarities? Male teacher, female teacher: An instrumental case study of teaching in a Head Start classroom," Teach. Teach. Educ., vol. 47, pp. 13$21,2015$.

[42] J. Peeters, T. Rohrmann, and K. Emilsen, "Gender balance in ECEC: why is there so little progress?," Eur. Early Child. Educ. Res. J., vol. 23, no. 3, pp. 302-314, 2015.

[43] M. Domingues and C. E. Gonçalves, "The Role of Parents in Talented Youth Sport. Does Context Matter?," Polish J. Sport Tour., vol. 20, no. 2, pp. 117-122, 2013.

[44] P. D. Turman, "Parental Sport Involvement: Parental Influence to Encourage Young Athlete Continued Sport Participation*," J. Fam. Commun., vol. 7, no. 3, pp. 151-175, 2007.

[45] P. A. Sánchez-Miguel, F. M. Leo, D. Sánchez-Oliva, D. Amado, and T. García-Calvo, "The importance of parents' behavior in their children's enjoyment and amotivation in sports," J. Hum. Kinet., vol. 36, no. 1, pp. 169-177, 2013. 